\title{
Organelle-associated rRNA Degradation
}

Jinliang Huang and Geng Wang*

Ministry of Education Key Laboratory of Bioinformatics, Cell Biology and Development Center, School of Life Sciences, Tsinghua University, Beijing 100084, China

*For correspondence: wangeng@hotmail.com

[Abstract] Cytosolic rRNAs are highly dynamic and can be degraded under conditions such as apoptosis, starvation and magnesium depletion. The degradation is also related to their specific localization, as fractions of cytosolic ribosomes are localized on the surfaces of intracellular organelles, such as endoplasmic reticulum (ER) and mitochondria. Such localized translation facilitates translocation of nascent proteins into these organelles co-translationally, contributing to fast responses to cellular stresses and precise regulations of the organelle. Here, we describe a protocol to establish the in organello system to investigate rRNA degradation on mitochondrial outer membrane or ER. The protocol consists of organelle isolation, rRNA degradation on organelles and agarose gel electrophoresis to examine the remaining rRNAs.

Keywords: In organello, Ribosomal RNA, Cytosolic rRNAs, rRNA degradation, Localized translation, Mitochondrion-associated ribosomes, ER-associated ribosomes

[Background] Cytosolic ribosomes, where protein translation takes place, have been shown to be localized to specific membranes within the cells, such as ER (Reid and Nicchitta, 2012) and mitochondrial outer membrane (Kellems and Butow, 1972), which couples protein synthesis to protein targeting and translocation (Mukhopadhyay et al., 2004). Such localized translation reduces the protein transportation cost and avoids mistargeting (Lesnik et al., 2015). In addition, localized translation contributes to fast responses to unfolded protein stress on ER (Reid et al., 2014) and modulates protein translation within mitochondria (Dennerlein et al., 2017; Richter-Dennerlein et al., 2016). The binding between cytosolic ribosomes and mitochondrial outer membrane have been previously investigated, and GTP, specific targeting sequences (Crowley and Payne, 1998) and MDI (Zhang et al., 2016) are all shown to be involved. However, how the mitochondrial outer membrane-associated cytosolic rRNAs are regulated by different conditions or mitochondrial proteins remains unclear, and how the ER-associated ribosomes differ from other pools of cytosolic ribosomes is not well studied. To gain a better understanding of these processes and their regulations in mammals, in organello systems are needed. However, no such systems have been established. Here, we describe a protocol to study in organello rRNA degradation on mitochondria or ER. The sample preparation procedures are minimized to reduce the operational errors. However, since this is an in organello system, the rRNA degradation observed may not reflect the real complexity in the cell. Particular caution needs to be taken in interpreting the results. 


\section{Materials and Reagents}

1. $1.5 \mathrm{ml}$ microcentrifuge tubes (Quality Scientific Plastics, catalog number: 509-GRD-Q)

2. $0.22 \mu \mathrm{m}$ filter (Merk, Millex-GP PES, catalog number: SLGP033RB)

3. Nuclease-free pipette tips (Quality Scientific Plastics, catalog numbers: T104RLS-Q, T090RLS-Q, and T112NXLRLS-Q)

4. Mannitol (AMRESCO, catalog number: 0122-500G)

5. Sucrose (AMRESCO, catalog number: 0335-500G)

6. HEPES free acid (AMRESCO, catalog number: 0511-1KG)

7. Sodium dodecyl sulfate (SDS) (AMRESCO, catalog number: 0227-1KG)

8. EDTA, disodium salt, dihydrate $\left(\mathrm{Na}_{2} \mathrm{EDTA} \cdot 2 \mathrm{H}_{2} \mathrm{O}\right)$ (AMRESCO, catalog number: 0105-1KG)

9. Agarose (BIOWEST, Regular Agarose G-10, catalog number: 111860)

10. Proteinase K (AMRESCO, catalog number: 0706-100MG)

11. Bromophenol blue (AMRESCO, ACS grade, catalog number: 0449-25G)

12. Tris (AMRESCO, catalog number: 0497-5KG)

13. Glacial acetic acid (Beijing Chemical Works, Analytic Reagent grade)

14. Nuclease-free water (AMRESCO, catalog number: E476-1L)

15. Glycerol (AMRESCO, catalog number:0854-1L)

16. $\mathrm{KOH}$ (Sigma-Aldrich, catalog number: P1767-500G)

17. Double distilled water $\left(\mathrm{ddH}_{2} \mathrm{O}\right)$

18. $\mathrm{NaOH}$ (sodium hydroxide pellets) (Shanghai Sangon Biotech, catalog number: A100173)

19. Tween20 (AMRESCO, product code: 0777-1L)

20. $\mathrm{NaCl}$ (AMRESCO, catalog number: 0241-1KG)

21. PBS (Corning, catalog number: 21-040-CVR)

22. Luminol/Enhancer solution (Thermo Fisher Scientific, catalog number: 1863096)

23. Anti-Mortalin antibody (Sigma-Aldrich, catalog number: G4045)

24. Anti-Calnexin antibody (Cell Signaling Technology, catalog number: 2433S)

25. Anti-Rabbit IgG (whole molecule)-Peroxidase (Sigma-Aldrich, catalog number: A0545)

26. Prestained Protein Ladder (Thermo Fisher Scientific, PageRuler, catalog number: 26616)

27. HEK293 (from Carla M. Koehler's lab at University of California, Los Angeles)

28. $10 \%$ SDS-PAGE gel (Homemade, refer to He, 2011 for detailed protocol)

29. Skim milk powder (OXOID, catalog number: LP0031)

30. BSA (Sigma-Aldrich, catalog number: P3761)

31. MitoPrep buffer (see Recipes)

32. $10 \%(w / v)$ SDS (see Recipes)

33. $0.5 \mathrm{M}$ EDTA ( $\mathrm{pH}$ 8.0) (see Recipes)

34. 2x DNA-SDS-EDTA buffer (see Recipes)

35. Proteinase $\mathrm{K}(1 \mathrm{mg} / \mathrm{ml})$ (see Recipes)

36. 50x TAE (see Recipes) 
37. $1 \times$ TBS-T (see Recipes)

38. $2 x$ protein loading buffer (see Recipes)

\section{Equipment}

1. Pipettes (RAININ, Pipet-Lite XLS)

2. Two heating blocks (Hangzhou Allsheng Instruments, Product Name: dry bath incubator, catalog number: MK200-2)

3. NanoDrop instrument (Thermo Fisher Scientific, NanoDrop 2000c Spectrophotometer)

4. Power supply (Tanon, catalog number: EPS 300)

5. Gel imaging system (Tanon, catalog number: 1600)

6. Centrifuges (Thermo Fisher Scientific, models: Sorvall Legend Micro 21 and Micro 21R)

7. $\mathrm{pH}$ meter (Sartorius, catalog number: PB-10)

8. $-80^{\circ} \mathrm{C}$ freezer (Thermo Fisher Scientific)

9. Nitrocellulose membrane (Merck, catalog number: HATF00010)

10. Vertical electrophoresis bath (Tanon, catalog number: VE-180)

11. Glass/Teflon homogenizer (Wheaton, catalog number: 358034)

12. Incubator

13. $4{ }^{\circ} \mathrm{C}$ refrigerator

14. $-20^{\circ} \mathrm{C}$ freezer

\section{$\underline{\text { Software }}$}

1. Tanon imaging (Tanon MP) and processing (Tanon GIS) software

2. ImageJ

3. GraphPad Prism 5

4. Microsoft PowerPoint 2010

\section{Procedure}

Note: Use nuclease-free tubes and tips (Materials and Reagents sections) for all the steps.

1. Crude mitochondria and ER isolation Note: The method for mitochondria isolation was adapted from a previously described protocol (Wang et al., 2015) with minor modifications. During organelle isolation, the $\mathrm{pH}$ value of MitoPrep buffer is 7.4 if not specified.

a. Collect HEK293 cells by centrifuging at $1,000 \times \mathrm{g}$ for $2 \mathrm{~min}$ at room temperature (RT). Discard the supernatant, and resuspend the cell pellet with $1 \mathrm{ml}$ of PBS. Spin again at $1,000 \times g$ for 2 min at RT. Discard the supernatant. 
Note: HEK293 cells were cultured in a 15-cm cell culture dish. With a density of $\sim 90 \%, \sim 3 x$ $10^{7}$ cells were harvested.

b. Resuspend the cells in $1.5 \mathrm{ml}$ ice-cold MitoPrep buffer and transfer the mixture to a $5 \mathrm{ml}$ glass/Teflon homogenizer pre-cooled in an ice bath. Perform 30 strokes on ice.

c. Transfer the homogenate into a $1.5 \mathrm{ml}$ microcentrifuge tube and centrifuge at $800 \times \mathrm{g}$ for 5 min at $4{ }^{\circ} \mathrm{C}$. Transfer the supernatant to a new microcentrifuge tube.

d. Resuspend the pellet in $1.5 \mathrm{ml}$ MitoPrep buffer. Perform 20 strokes on ice. Transfer the homogenate into a $1.5 \mathrm{ml}$ microcentrifuge tube and centrifuge at $800 \times \mathrm{g}$ for $5 \mathrm{~min}$ at $4{ }^{\circ} \mathrm{C}$. Transfer the supernatant to a new microcentrifuge tube.

e. Spin the supernatants from Steps $1 \mathrm{c}$ and $1 \mathrm{~d}$ at $800 \times \mathrm{g}$ for $5 \mathrm{~min}$ at $4{ }^{\circ} \mathrm{C}$.

f. Transfer the supernatants to new microcentrifuge tubes and centrifuge at $11,000 \times g$ for 5 min at $4{ }^{\circ} \mathrm{C}$. The resulting pellets are crude mitochondria.

g. The supernatants are transferred into two new microcentrifuge tubes and spun at $21,000 \times g$ for $10 \mathrm{~min}$ at $4{ }^{\circ} \mathrm{C}$. The pellets are crude ER.

h. Combine the pellets of mitochondria or ER from the two tubes by resuspending them in $1 \mathrm{ml}$ MitoPrep buffer. Spin at $11,000 \times \mathrm{g}$ for $5 \mathrm{~min}$ or $21,000 \times \mathrm{g}$ for $10 \mathrm{~min}$ to spin down mitochondria or ER respectively.

i. Discard the supernatant and resuspend mitochondria or ER with $30 \mu$ of MitoPrep buffer $(\mathrm{pH} 7.4)$.

Note: Optiprep gradients can be used for further purification, if purer fractions are needed.

j. Measure protein concentrations with a NanoDrop instrument after diluting $1 \mu$ l of protein sample with $19 \mu \mathrm{l}$ of $0.6 \%(\mathrm{w} / \mathrm{v}) \mathrm{SDS}$. The original protein concentrations are the measured values multiplied by 20 .

Note: After we add $1 \mu \mathrm{l}$ of protein sample to $19 \mu \mathrm{l}$ of $0.6 \%$ SDS, the total volume becomes $20 \mu \mathrm{l}$, that means the concentration of this diluted protein sample is $1 / 20$ of its original concentration. So, we can calculate the original protein concentration by a factor of 20 . Usually, $3 \times 10^{7}$ cells can yield $800 \mu \mathrm{g}$ of mitochondria and $150 \mu \mathrm{g}$ of ER.

2. Take out $200 \mu \mathrm{g}$ of mitochondria (in about $15 \mu \mathrm{l}$ of MitoPrep buffer, $\mathrm{pH}$ 7.4), or $50 \mu \mathrm{g}$ of ER (in about $10 \mu \mathrm{l}$ of MitoPrep buffer, $\mathrm{pH}$ 7.4), and bring the volume to $60 \mu \mathrm{l}$ with MitoPrep buffer with a $\mathrm{pH}$ value of interest ( $\mathrm{pH} 7.4$ and 6.5 are the two values we routinely use). Keep the samples on ice.

Notes:

a. Metal ions, metal chelators, or other conditions can be added to the sample before the next step. Some conditions that have effects on the degradation of mitochondrion-associated cytosolic rRNAs have been listed in Table 1. 
Table 1. Conditions that affect the degradation of mitochondrion-associated cytosolic rRNAs

\begin{tabular}{|l|l|l|}
\hline Conditions & Concentration/Temperature & Effects \\
\hline $\mathrm{MgCl}_{2}$ & $2 \mathrm{mM}$ or $20 \mathrm{mM}$ & Minor or major inhibition \\
\hline EDTA & $2 \mathrm{mM}$ & Activation \\
\hline ATP & $8 \mathrm{mM}$ & Inhibition \\
\hline Incubation temperature & $25^{\circ} \mathrm{C}$ & Inhibition compared to $37^{\circ} \mathrm{C}$ \\
\hline
\end{tabular}

b. For ER-associated rRNA degradation, the $\mathrm{pH}$ value of MitoPrep buffer matters: when the $\mathrm{pH}$ is 7.4 , degradation is slower; when the $\mathrm{pH}$ is lowered to 6.5 , the degradation becomes much faster. All these effects have been described in the original paper (Huang et al., 2018).

3. Divide each sample $(60 \mu \mathrm{l})$ into 3 microcentrifuge tubes ( $20 \mu \mathrm{l}$ per tube). Store one tube at the $-80{ }^{\circ} \mathrm{C}$ freezer as the first time point $(0 \mathrm{~min})$. Transfer the other 2 tubes to $37^{\circ} \mathrm{C}$ in a heating block. Incubate the two samples for 30 and 60 min respectively. At each time point, transfer one tube to $-80^{\circ} \mathrm{C}$ freezer. Store the samples at $-80^{\circ} \mathrm{C}$ for at least $15 \mathrm{~min}$ before the next step. Note: For quality control, prepare another set of the samples and perform the same degradation steps. Then mix the samples with an equal volume of $2 x$ protein loading buffer with $D T T$, and heat them at $95{ }^{\circ} \mathrm{C}$ for $5 \mathrm{~min}$. Separate the proteins in the samples on a $10 \%$ SDS-PAGE gel. After running the gel at $150 \mathrm{~V}$ for $60 \mathrm{~min}$, transfer the proteins in the gel to a nitrocellulose membrane at $450 \mathrm{~mA}$ for $70 \mathrm{~min}$ and blot the membrane by standard western blotting method. In brief, incubate the membrane at RT for $1 \mathrm{~h}$ in 5\% skim milk, probe it with primary antibody in $1 x$ TBS-T at RT for $1 \mathrm{~h}$, wash 4 times with $1 x$ TBS-T (5 min/time), incubate with secondary antibody in $1 x$ TBS-T at RT for $1 \mathrm{~h}$, and then wash 4 times with $1 x$ TBS-T (5 min/time). Use Luminol/Enhancer solution for detection of the proteins. Marker proteins used for mitochondria and ER fractions are Mortalin $(73.7 \mathrm{kDa})$ and Calnexin ( $\sim 68 \mathrm{kDa})$ respectively. The actual position for Mortalin on a gel is between 70 and $100 \mathrm{kDa}$, and the position for Calnexin is around $100 \mathrm{kDa}$.

4. Take out samples from the $-80^{\circ} \mathrm{C}$ freezer and add $20 \mu \mathrm{l}$ of $2 \mathrm{x}$ DNA-SDS-EDTA buffer. Vortex, and incubate the samples at $70^{\circ} \mathrm{C}$ for $5 \mathrm{~min}$. Cool the samples to RT.

5. Add $0.5 \mu \mathrm{l}$ of $1 \mathrm{mg} / \mathrm{ml}$ proteinase $\mathrm{K}$ to each sample and incubate it at $37^{\circ} \mathrm{C}$ in a heating block for 5 min.

6. Run the samples on a $1.5 \%(\mathrm{w} / \mathrm{v})$ agarose gel with ethidium bromide (EB) $(0.5 \mu \mathrm{g} / \mathrm{ml})$ for 15 min at $150 \mathrm{~V}$ in $1 \mathrm{X}$ TAE buffer. Capture gel images to check RNA degradation pattern with a UV-based gel imaging system.

7. The flow sheet of this protocol is shown in Figure 1. 


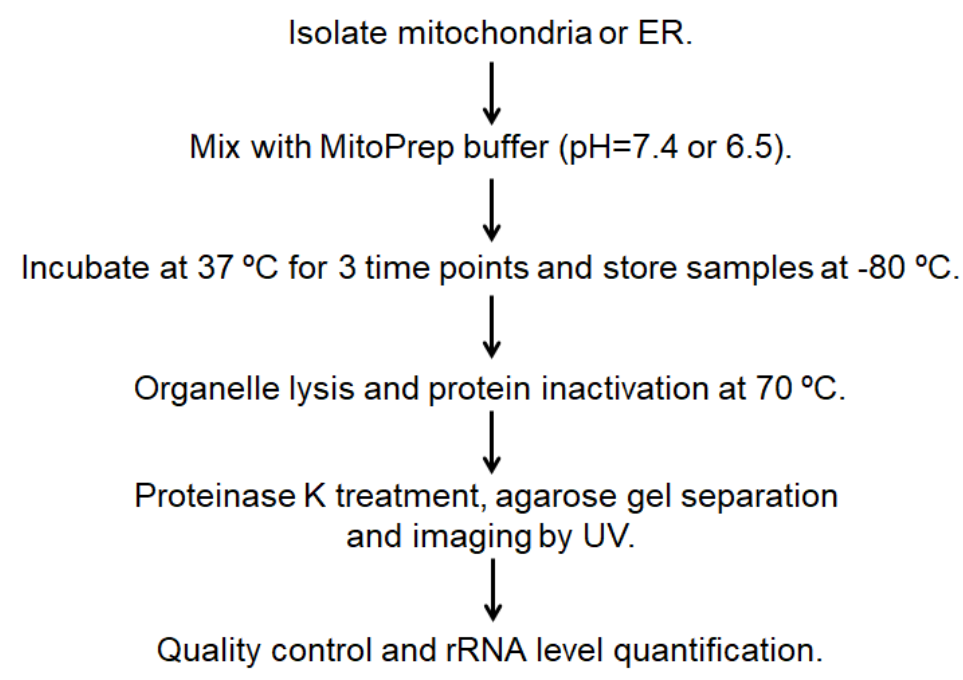

Figure 1. The flow sheet of this protocol

\section{Data analysis}

Representative data (Figures 2-4)

A

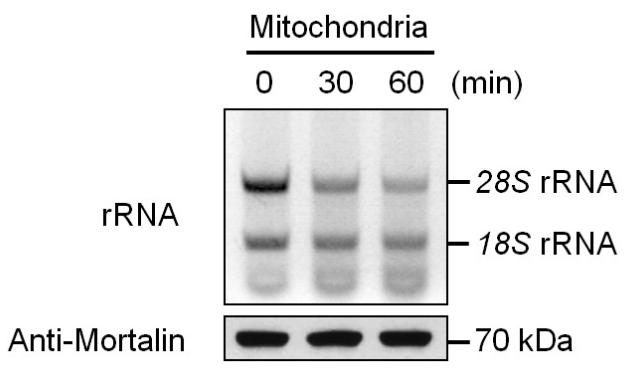

B

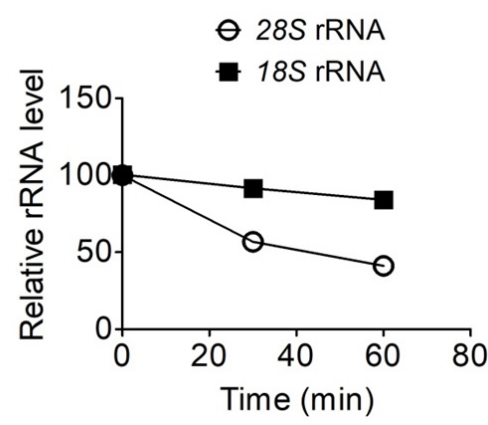

Figure 2. In organello degradation of mitochondrion-associated cytosolic rRNAs. A. Mitochondria were suspended in MitoPrep buffer and incubated for 0, 30 or $60 \mathrm{~min}$. The top panel shows the agarose gel image of mitochondrion-associated cytosolic rRNAs at three time points. The two major bands are cytosolic 28S rRNA and 18S rRNA. The bottom panel is an immunoblot of mitochondrial matrix protein Mortalin (Mw: $73.7 \mathrm{kDa}$ ), which is used as a loading control. B. Quantification of the rRNAs in Panel A. 
A

Mitochondria

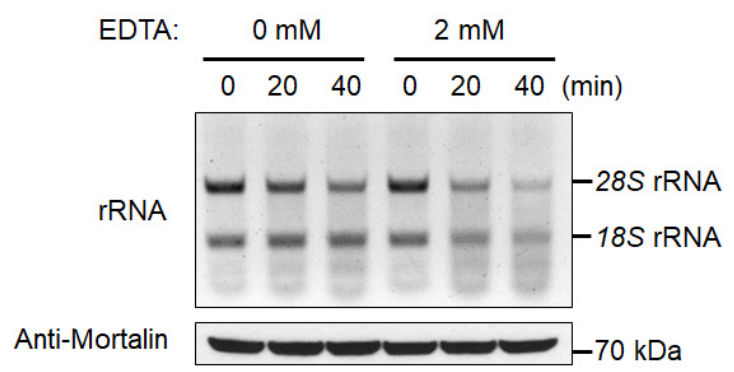

B

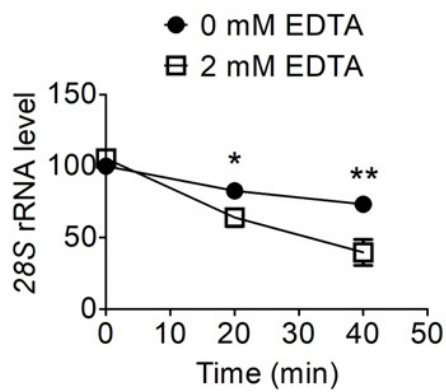

C

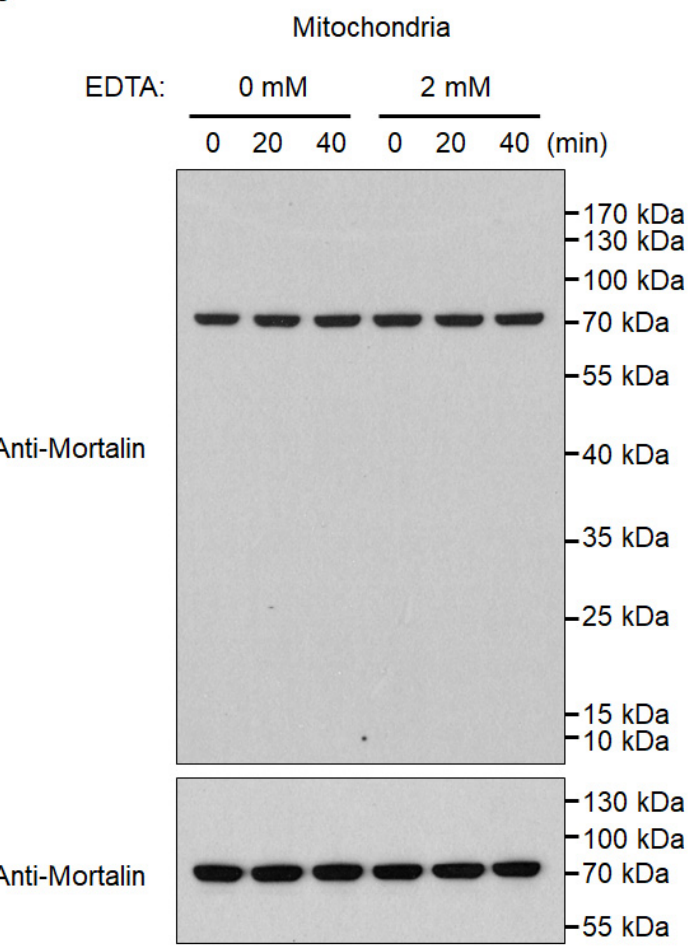

Figure 3. The effects of EDTA on the in organello degradation of mitochondrion-associated cytosolic rRNAs. A. Mitochondria were suspended in MitoPrep buffer, and incubated for 0, 20 or $40 \mathrm{~min}$ with or without $2 \mathrm{mM}$ EDTA. The top panel shows the agarose gel image of mitochondrion-associated cytosolic rRNAs at three time points. The two major bands are cytosolic $28 S$ rRNA and $18 S$ rRNA. The bottom panel is an immunoblot of mitochondrial matrix protein Mortalin (Mw: $73.7 \mathrm{kDa}$ ), which is used as a loading control. B. Quantification of 28S rRNA in Panel A. C. Antibody specificity confirmation, protein loading control samples from A were separated with SDS-PAGE gels and transferred to nitrocellulose membrane. The entire membrane (upper panel) or the cropped membrane (bottom panel) was probed with anti-Mortalin antibody. 
A
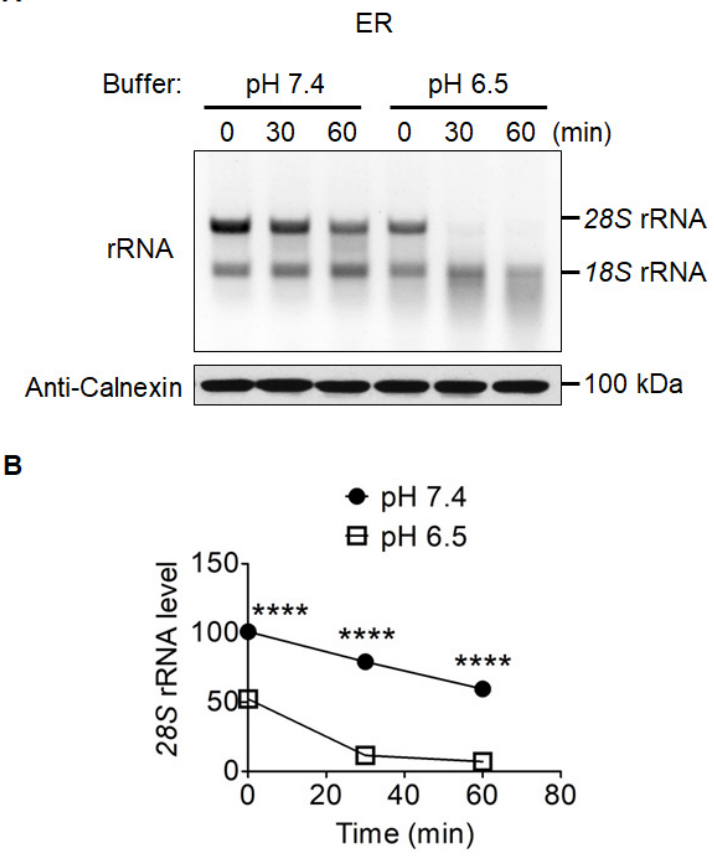

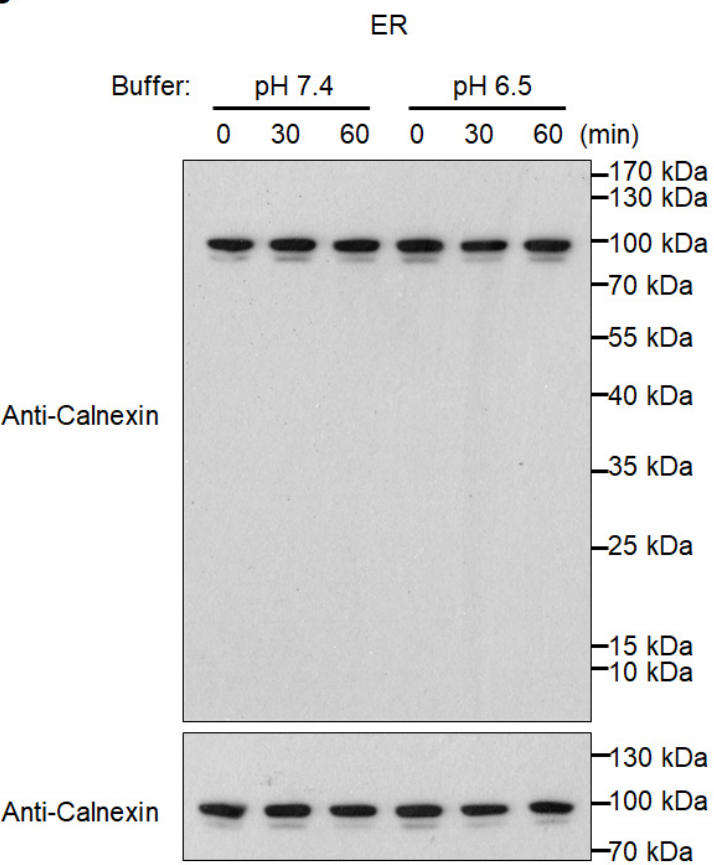

Figure 4. Effects of $\mathrm{pH}$ on the in organello degradation of ER-associated cytosolic rRNAs. A. ER was suspended in MitoPrep buffer with a pH of 7.4 or 6.5, and incubated for 0,30 or 60 min. The top panel shows the agarose gel image of ER-associated cytosolic rRNAs at three time points. The two major bands are cytosolic 28S rRNA and 18S rRNA. The bottom panel is an immunoblot of ER protein Calnexin (the position of the protein on the gel is around $100 \mathrm{kDa}$ ), which is used as a loading control. B. Quantification of $28 S$ rRNA in Panel A. C. Antibody specificity confirmation, protein loading control samples from A were separated with SDS-PAGE gels and transferred to nitrocellulose membrane. The entire membrane (upper panel) or the cropped membrane (bottom panel) was probed with Anti-Calnexin antibody.

\section{Data processing}

The gel image was captured with Tanon 1600 Gel Image System (Tanon), and cropped using Photoshop.

\section{Data analysis}

The intensity of the bands on each gel was measured with ImageJ, normalized to the protein loading control, and analysed with GraphPad Prism.

For an original image captured on Gel Image System (the background is black, while the bands are white), here is a brief introduction on how to use ImageJ for quantification. Open software ImageJ. Select "Rectangular" tool (this is default choice), and draw a rectangle covering the RNA band at the first time point. Press shortcut " $\mathrm{Ctrl}+\mathrm{M}$ " to measure the band intensity. Move the same rectangle horizontally to RNA band at the second or third time point, and then press shortcut "Ctrl + M" to measure the band intensity. After all the time points are measured, move the same rectangle to a typical background area, and then press shortcut "Ctrl + M" to measure background intensity. 
Calculation method: Measure the RNA signal by subtracting the background intensity from the band intensity to get the absolute intensity of each band. Set the signal at the first time point as 100 , and calculate the second and third ones by dividing the absolute signal of the RNA band to that of the first time point.

Statistical comparisons were performed using unpaired $t$-tests $(n=3)$; ${ }^{\star} P<0.05,{ }^{* *} P<0.01$, ${ }^{* \star \star} P$ $<0.001,{ }^{\star \star \star \star} P<0.0001$. Data are presented as mean \pm standard deviation (S.D.). Data sets at each time point were analyzed individually.

\section{$\underline{\text { Recipes }}$}

1. MitoPrep buffer

$0.225 \mathrm{M}$ mannitol

$0.075 \mathrm{M}$ sucrose

20 mM HEPES (pH 7.4 or $\mathrm{pH} 6.5)$

a. Dissolve $2.05 \mathrm{~g}$ of mannitol (Mw: 182.17), $1.28 \mathrm{~g}$ of sucrose (Mw: 342.3 ), and $0.2383 \mathrm{~g}$ of

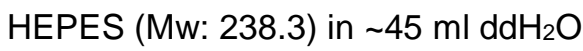

b. Adjust $\mathrm{pH}$ to 7.4 or 6.5 with $1 \mathrm{M} \mathrm{KOH}$, and add $\mathrm{ddH}_{2} \mathrm{O}$ to the final volume of $50 \mathrm{ml}$

c. Filter through $0.22 \mu \mathrm{m}$ filter, and store at $4{ }^{\circ} \mathrm{C}$

2. $10 \%(w / v)$ SDS

a. Dissolve $10 \mathrm{~g}$ of SDS in $100 \mathrm{ml}$ of $\mathrm{ddH}_{2} \mathrm{O}$, stir until completely dissolved. Store at RT

b. Dilute $10 \%$ SDS to $0.6 \%$ SDS with $\mathrm{ddH}_{2} \mathrm{O}$. Store at RT

3. $0.5 \mathrm{M}$ EDTA ( $\mathrm{pH} 8.0)$

a. Add $9.306 \mathrm{~g}$ of EDTA (Mw: 372.24 ) to $\sim 40 \mathrm{ml}$ of $\mathrm{ddH}_{2} \mathrm{O}$, stir and slowly adjust the $\mathrm{pH}$ to 8.0 with $\mathrm{NaOH}$, and make up to $50 \mathrm{ml}$ with $\mathrm{ddH}_{2} \mathrm{O}$

b. Filter through a $0.22 \mu \mathrm{m}$ filter and store at $4{ }^{\circ} \mathrm{C}$

Note: EDTA will not fully dissolve until the $\mathrm{pH}$ is close to 8.0.

4. 2x DNA-SDS-EDTA buffer

2x DNA loading buffer, supplemented with $0.5 \%$ SDS and $15 \mathrm{mM}$ EDTA

First prepare 10x DNA loading buffer:

For a $10 \mathrm{ml}$ solution, dissolve $0.2 \mathrm{~g}$ of SDS and $0.01 \mathrm{~g}$ of bromophenol blue in $5 \mathrm{ml}$ of $\mathrm{ddH}_{2} \mathrm{O}$, mix with $5 \mathrm{ml}$ of glycerol. Store at RT

\section{To prepare $100 \mu \mathrm{l} 2 \mathrm{x}$ DNA-SDS-EDTA buffer:}

Mix $72 \mu$ l of nuclease-free water with $20 \mu \mathrm{l}$ of 10x DNA loading buffer, add $5 \mu \mathrm{l}$ of $10 \%$ SDS and $3 \mu$ of $0.5 \mathrm{M}$ EDTA $(\mathrm{pH} 8.0)$

5. Proteinase $\mathrm{K}(1 \mathrm{mg} / \mathrm{ml})$

Dissolve $1 \mathrm{mg}$ of proteinase $\mathrm{K}$ in $1 \mathrm{ml}$ of nuclease-free water, aliquot and store at $-20^{\circ} \mathrm{C}$

6. $50 \times \mathrm{TAE}$

$2 \mathrm{M}$ Tris

$1 \mathrm{M}$ acetic acid 
50 mM EDTA

a. Dissolve $242 \mathrm{~g}$ of Tris (Mw: 121.14), $37.2 \mathrm{~g}$ of $\mathrm{Na}_{2} \mathrm{EDTA} \cdot 2 \mathrm{H}_{2} \mathrm{O}$ (Mw: 372.24$)$ and $57.1 \mathrm{ml}$ of glacial acetic acid (molar concentration: $17.5 \mathrm{M}$ ) in $\sim 900 \mathrm{ml}$ of $\mathrm{ddH}_{2} \mathrm{O}$, add $\mathrm{dd}_{2} \mathrm{O}$ to the final volume of $1 \mathrm{~L}$. Store at RT

b. Prepare $1 \times$ TAE by diluting $50 \times$ TAE with $d_{d H_{2}} \mathrm{O}$

7. $1 \times$ TBS-T

a. Dilute $10 x$ TBS stock with $0.1 \%(v / v)$ of Tween20 and $\mathrm{ddH}_{2} \mathrm{O}$ to make $1 \times$ TBS-T

b. To prepare 10x TBS ( $1 \mathrm{~L}$ ), dissolve $24.2 \mathrm{~g}$ of Tris and $80 \mathrm{~g}$ of $\mathrm{NaCl}$ in $\sim 900 \mathrm{ml}$ of $\mathrm{ddH}_{2} \mathrm{O}$, and adjust the $\mathrm{pH}$ to 7.6 with $\mathrm{HCl}$

8. $2 x$ protein loading buffer

a. First prepare $100 \mathrm{ml}$ of $0.5 \mathrm{M}$ Tris- $\mathrm{HCl}(\mathrm{pH}$ 6.8). Dissolve $6.05 \mathrm{~g}$ of Tris (Mw: 121.14) in $\sim 90 \mathrm{ml}$ of $\mathrm{dd}_{2} \mathrm{O}$, adjust $\mathrm{pH}$ to 6.8 with $\mathrm{HCl}$. Add $\mathrm{ddH}_{2} \mathrm{O}$ to the final volume of $100 \mathrm{ml}$. Store at RT

b. To prepare $10 \mathrm{ml} 2 x$ protein loading buffer, mix $1.25 \mathrm{ml}$ of $0.5 \mathrm{M} \mathrm{Tris}-\mathrm{HCl}(\mathrm{pH} 6.8), 0.2 \mathrm{ml}$ of $0.5 \%(\mathrm{w} / \mathrm{v})$ bromophenol blue, $2.5 \mathrm{ml}$ of glycerol, $2 \mathrm{ml}$ of $10 \% \mathrm{SDS}$ and $3.55 \mathrm{ml}$ of $\mathrm{ddH}_{2} \mathrm{O}$, store at RT

c. A final concentration of $30 \mathrm{mM}$ DTT is added in the $2 \mathrm{x}$ protein loading buffer right before use

\section{Acknowledgments}

This work was supported by Grant 2017YFA0504600 from the Priority Research Program of the Ministry of Science and Technology of China, by Grants 31371439 and 91649103 from the National Natural Science Foundation of the People's Republic of China, and by funds from the Ministry of Education of the People's Republic of China 1000 Talents Youth Program. This protocol was modified from Huang et al. (2018).

\section{Competing interests}

The authors declare no conflicts of interest with the contents of this article.

\section{References}

1. Crowley, K. S. and Payne, R. M. (1998). Ribosome binding to mitochondria is regulated by GTP and the transit peptide. J Biol Chem 273(27): 17278-17285.

2. Dennerlein, S., Wang, C. and Rehling, P. (2017). Plasticity of mitochondrial translation. Trends Cell Biol 27(10): 712-721.

3. He, F. (2011). Laemmli-SDS-PAGE. Bio-protocol 1(11): e80.

4. Huang, J., Liu, P. and Wang, G. (2018). Regulation of mitochondrion-associated cytosolic 
ribosomes by mammalian mitochondrial ribonuclease T2 (RNASET2). J Biol Chem 293(51): 19633-19644.

5. Kellems, R. E. and Butow, R. A. (1972). Cytoplasmic-type $80 \mathrm{~S}$ ribosomes associated with yeast mitochondria. I. Evidence for ribosome binding sites on yeast mitochondria. $\mathrm{J}$ Biol Chem 247(24): 8043-8050.

6. Lesnik, C., Golani-Armon, A. and Arava, Y. (2015). Localized translation near the mitochondrial outer membrane: An update. RNA Biol 12(8): 801-809.

7. Mukhopadhyay, A., Ni, L. and Weiner, H. (2004). A co-translational model to explain the in vivo import of proteins into HeLa cell mitochondria. Biochem J 382(Pt 1): 385-392.

8. Reid, D. W., Chen, Q., Tay, A. S., Shenolikar, S. and Nicchitta, C. V. (2014). The unfolded protein response triggers selective mRNA release from the endoplasmic reticulum. Cell 158(6): 1362-1374.

9. Reid, D. W. and Nicchitta, C. V. (2012). Primary role for endoplasmic reticulum-bound ribosomes in cellular translation identified by ribosome profiling. J Biol Chem 287(8): 5518-5527.

10. Richter-Dennerlein, R., Oeljeklaus, S., Lorenzi, I., Ronsor, C., Bareth, B., Schendzielorz, A. B., Wang, C., Warscheid, B., Rehling, P. and Dennerlein, S. (2016). Mitochondrial protein synthesis adapts to influx of nuclear-encoded protein. Cell 167(2): 471-483 e410.

11. Wang, G., Shimada, E., Nili, M., Koehler, C. M. and Teitell, M. A. (2015). Mitochondria-targeted RNA import. Methods Mol Biol 1264: 107-116.

12. Zhang, Y., Chen, Y., Gucek, M. and Xu, H. (2016). The mitochondrial outer membrane protein MDI promotes local protein synthesis and mtDNA replication. EMBO J 35(10): 1045-1057. 